\title{
Cytotoxic effect of oxaloacetate on HepG2-human hepatic carcinoma cells via apoptosis and ROS accumulation
}

\author{
Y. JIAO, L. JI, Y. KUANG, Q. YANG* \\ Department of Pathogenobiology, College of Basic Medical Sciences, Jilin University, Changchun 130021, Jilin Province, China \\ ${ }^{*}$ Correspondence: yangq@jlu.edu.cn
}

Received August 18, 2016/ Accepted October 3, 2016

\begin{abstract}
Oxaloacetate $(\mathrm{OA})$ is one of the intermediates of the Krebs cycle. In addition to its role in energy production, OA may have other effects on the cell. We report here that OA could have a cell type dependent cytotoxic effect on the human hepatic carcinoma cell line HepG2 through induction of apoptosis and reactive oxygen species (ROS) accumulation. In our study, OA decreased the viability and colony formation of HepG2 cells and induced cell death. Caspase-3 activity was increased, the pro-apoptotic protein Bax was up-regulated, and the anti-apoptotic protein Bcl-2 was down-regulated in OA-treated HepG2 cells indicating that apoptosis through the intrinsic pathway was involved in the cell death. The ROS level in OA-treated HepG2 cells was increased. The anti-oxidant N-acetylcysteine (NAC) and glutathione (GSH) prevented the OA-induced decrease in cell but did not alter the enhanced apoptotic Bax/Bcl-2 mRNA ratio. These results suggest that the OA-induced apoptosis of HepG2 cell is not driven by oxidative damage and at least two distinct mechanisms, one mediated by ROS and one involving apoptosis, result in the cytotoxic effects of OA on HepG2 cells. These studies expand the biological functional repertoire of $\mathrm{OA}$ and provide a mechanism by which hepatocellular carcinoma may be targeted by OA.
\end{abstract}

Key words: oxaloacetate, HepG2 cells, apoptosis, reactive oxygen species

Oxaloacetate $(\mathrm{OA})$ is an intermediate of the Krebs cycle and participates in the energy production via a reaction with acetyl-CoA [1]. During this metabolic process, OA is exhausted and recovered by metabolism of glutamine. This process is more active in rapidly growing cells, such as tumor cells, in which nearly $90 \%$ of OA can be recovered by metabolism of glutamine, promoting mitochondrial oxidative phosphorylation and increasing the stores of cellular energy $[2,3]$. In addition to its role in the Krebs cycle as a substrate, OA may have other biological effects. OA can promote proliferation in cultured cells [4] and alleviate glutamine-depletion mediated apoptosis [5, 6]. The mechanism of OA-induced cell proliferation is poorly understood and believed to be unrelated to its role in the Krebs cycle [4]. Our studies showed that $\mathrm{OA}$ induced cellular death in a cell type-dependent manner. Excess treatment with $\mathrm{OA}$ induced cell death in the human hepatic carcinoma cell line HepG2 but not in human cervical carcinoma cell line HeLa. Interestingly, citrate, another intermediate of the Krebs cycle, induces apoptosis [7-9]. This phenomenon has not been previously reported for OA to the best of our knowledge. In the present study, we hypothesized that the cytotoxic effect of OA on HepG2 cells may be related to induction of apoptosis and ROS accumulation.

Hepatocellular carcinoma (HCC) is one of the most globally prevalent malignancies and a frequent cause of cancer-related death $[10,11]$. HCC is characterized by elevated glycolysis, gluconeogenesis, $\beta$-oxidation with reduced activity of the tricarboxylic acid cycle and $\Delta-12$ desaturase and increased levels of antioxidants, together with decreased inflammatory-related polyunsaturated fatty acids and phospholipase A2 [12]. Currently, the major clinical treatment for HCC is surgical removal, but high recurrence rates limit long-term patient survival [13]. There is an urgent need for more effective HCC treatment, and studies on the metabolic mechanisms of cancer may provide insight into novel therapeutic strategies [14]. The discovery of citrate's cytotoxic effects on gastric cancer cells suggests potential treatment options for cancer $[8,15]$. In the present study, we found that OA selectively induced death in the human hepatic carcinoma cell line HepG2 through apoptosis and 
ROS accumulation, which suggests future treatment options for hepatocellular carcinoma.

\section{Materials and methods}

Reagents. OA was purchased from Sigma-Aldrich (St Louis, MO, USA). The primers used for RT-PCR were synthesized by Sangon (Shanghai, China).

Cell culture. HepG2 cells and HeLa cells were purchased from the Cell Bank of Shanghai Institute of Biochemistry and Cell Biology. The cells were cultured in Dulbecco's modified Eagle's medium (DMEM, Gibico, USA) supplemented with $10 \%$ fetal bovine serum (FBS) (HyClone, USA), 1\% penicillin-streptomycin $(100 \mathrm{U} / \mathrm{mL}$ penicillin and $100 \mu \mathrm{g} / \mathrm{mL}$ streptomycin) and $50 \mathrm{mM}$ HEPES (Beyotime, China). The cells were maintained in a 5\% CO2 humidified atmosphere at $37^{\circ} \mathrm{C}$.

Cell viability assay. Cell viability was assessed using MTT assays. Briefly, cells were grown in a final volume of $100 \mu \mathrm{l}$ DMEM medium containing 10\% FBS per well in 96-well plates at a density of $7 \times 10^{4}$ cells $/ \mathrm{ml}$. After 24 hours, the cells were treated with 50, 75 and $100 \mathrm{mM}$ of OA for 24 hours or treated with 75 or $150 \mathrm{mM}$ OA plus different concentrations of antioxidants for 24 hours. MTT (3- [4,5-dimethylthiazol2-yl] -2,5 diphenyltetrazolium bromide)( Beyotime, China) was added to each well at a final concentration of $0.5 \mathrm{mg} / \mathrm{ml}$ and incubated for 4 hours in a moist chamber at $37^{\circ} \mathrm{C}$. The medium was then removed and $0.1 \mathrm{ml}$ DMSO was added. The absorbance $(\mathrm{A})$ of the formazan product was measured at $490 \mathrm{~nm}$ with a microtiter plate reader (Bio-Tek, Winooski, VT, USA).

Morphology of HeLa and HepG2 cells. HeLa and HepG2 cells were seeded in 96-well culture plates. After 24 hours, OA was added to the wells at concentrations of 0 or $75 \mathrm{mM}$ in DMEM medium supplied with 10\% FBS for 24 hours. The morphological changes in the cells were observed under an inverted optical microscope (Nikon, Japan).

Colony formation assay. HepG2 cells were plated in 6-well plates at 200 cells per well in $2 \mathrm{ml}$ of DMEM for 24 hours. OA was added to a final concentration of $75 \mathrm{mM}$. Then the media was not changed throughout the course of the experiment. After 7-10 days, colonies were fixed in methanol and stained with $0.1 \%$ crystal violet. Dye was extracted with $10 \%$ acetic acid and the relative absorbance was determined at $595 \mathrm{~nm}$ with a spectrophotometer [16].

Flow cytometry analysis of cell death. The induction of cell death by OA was evaluated by double staining with propidium iodide (PI) and annexin V-FITC. After treatment with $75 \mathrm{mM}$ OA for 24 hours, cells were harvested, washed twice with PBS, and assayed for cell death with a PI and annexin V-FITC assay kit (Beyotime, China). Briefly, $10^{5}$ cells were resuspended in a binding buffer, stained with $5 \mu \mathrm{l}$ of annexin V-FITC for 10 minutes, and then stained with $10 \mu$ of PI for another 10 minutes. The cells were immediately analyzed with a flow cytometer (FACScan; BD Biosciences, Milano, Italy).
Caspase-3 activity assay. In vitro caspase- 3 protease activity was measured using a caspase- 3 assay kit (Beyotime, China). According to the manufacturer's instruction, HepG2 cells were treated with $\mathrm{OA}$ at a concentration of $75 \mathrm{mM}$ for 1 or 3 hours. The cells were then lysed and prepared to detect the chromophore p-nitroanilide (pNA) after cleavage from the labeled substrate Ac-DEVD-pNA. The absorbance was measured at wavelength of $405 \mathrm{~nm}$ with a microtiter plate reader.

RNA isolation and RT-PCR assay. To determin the Bcl-2 and Bax mRNA levels in HepG2 cells, RT-PCR was performed. Total RNA of the cells was isolated from HepG2 cell using RNA plus (TaKaRa). Then, $5 \mu \mathrm{g}$ of RNA, $1 \mu$ of Anchored Oligo(dT) $18,10 \mu \mathrm{l}$ of $2 \times \mathrm{TS}$ Reaction Mix and $1 \mu \mathrm{l}$ of TransScript RT/RI Enzyme Mix (Transgene) were mixed and the final volume was brought up to $20 \mu \mathrm{l}$ with dimethyl pyrocarbonate (DEPC)-treated water. The reaction mixture was then incubated at $42{ }^{\circ} \mathrm{C}$ for 30 minutes and $85^{\circ} \mathrm{C}$ for 5 minutes. PCR amplification of DNA was performed in a reaction volume of $20 \mu \mathrm{l}$ containing $1 \mu \mathrm{l}$ of template cDNA, $1 \mu \mathrm{l}$ of each set of primers at a concentration of $10 \mathrm{pm}, 10 \mu \mathrm{l}$ of the $2 \times$ EasyTaq PCR SuperMix and $7 \mu \mathrm{l}$ of $\mathrm{ddH}_{2} \mathrm{O}$. The primers used in the study included forward (5-CGACGACTTCTCCCGCCGCTACCGC-3) and reverse (5-CCGCATGCTGGGGCCGTACAGTTCC-3) primers for human Bcl-2, forward (5-GTGCACCAAGGTGCCGGAAC-3) and reverse (5-TCAGCCCATCTTCTTCCAGA-3) primers for human $\mathrm{Bcl}-2$, and forward (5-GAAGGTGAAGGTCGGAGTC-3) and reverse (5-GAAGATGGTGATGGGATTTC-3) primers for human GAPDH an internal control for the PCR. The expected size of the PCR products was $318 \mathrm{bp}$ for Bcl-2, $205 \mathrm{bp}$ for Bax, and $226 \mathrm{bp}$ for GAPDH. PCR was carried out using a GeneAmp 9600 PCR system (Perkin-Elmer, Norwalk, CT, U.S.A.) under the following conditions: initial denaturation at $94^{\circ} \mathrm{C}$ for 5 minutes followed by 36 amplification cycles consisting of denaturation at $94^{\circ} \mathrm{C}$ for 30 seconds, annealing at $54^{\circ} \mathrm{C}$ for 30 seconds, and extension at $72^{\circ} \mathrm{C}$ for 60 second, and a final extension step at $72{ }^{\circ} \mathrm{C}$ for 10 minutes. The mRNA levels the RT-PCR product for each of the mRNA species were calculated densitometrically using Molecular Analyst TM version 1.4.1 (Bio-Rad, Hercules, CA, U.S.A.).

Detection of ROS accumulation. To detect ROS accumulation, we used a Reactive Oxygen Assay Kit from Beyotime, China. Briefly, HepG2 cells were treated with $75 \mathrm{mM}$ OA for 16 hours, and the cells were collected and exposed to serumfree medium containing $10 \mu \mathrm{M}$ DCFH-DA. After 20 minutes of incubation in the dark, cells were washed with DMEM three times, and fluorescence intensity was measured by fluorescence microscopy and flow cytometry with excitation and emission wavelengths of 488 and $525 \mathrm{~nm}$, respectively.

Statistical analysis. All experimental data are expressed as the mean \pm SD from at least three independent experiments. Single comparisons between groups were performed using paired, two-tailed Student's t-test, and statistical significance was set at $P<0.01$. 


\section{Results}

Effects of OA on viability, morphology and colony formation of HepG2 and HeLa cells. HepG2 cell viability was reduced by $\mathrm{OA}$ treatment in a dose-dependent manner. The IC50 value of OA for inhibition of HepG2 cell viability was $61.47 \pm 0.73 \mathrm{mM}$. At concentrations of 50,75 and $100 \mathrm{mM}$, OA reduced the viability of HepG2 cells to $78.77 \pm 0.169 \%$, $36.1 \pm 0.085 \%$, and $8.0 \pm 0.003 \%$ of the control value, respectively. However, the same concentrations of OA had no significant effect on HeLa cell vialbility (Figure 1A). We also performed a dose-response experiment to access the cytotoxic effects of

A
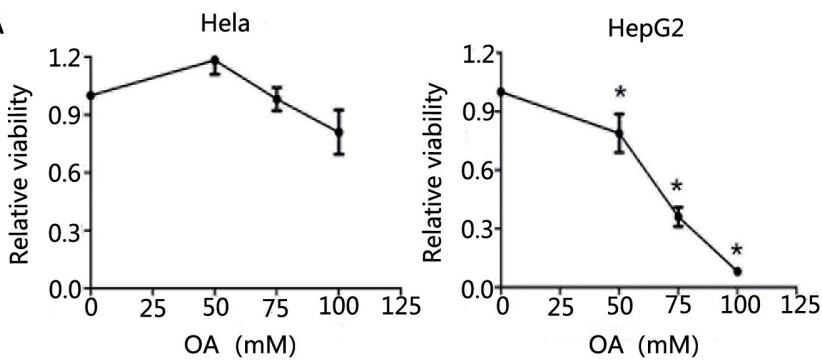

B

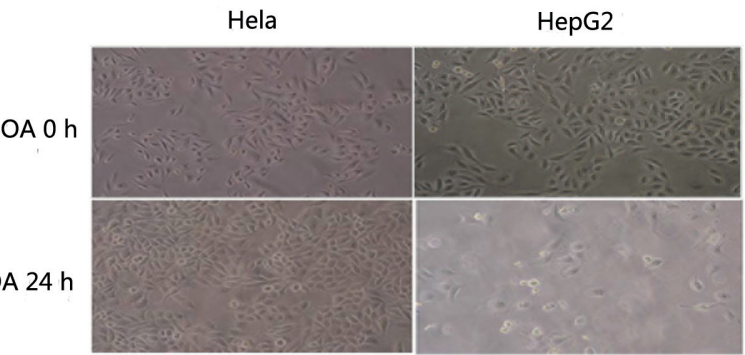

C
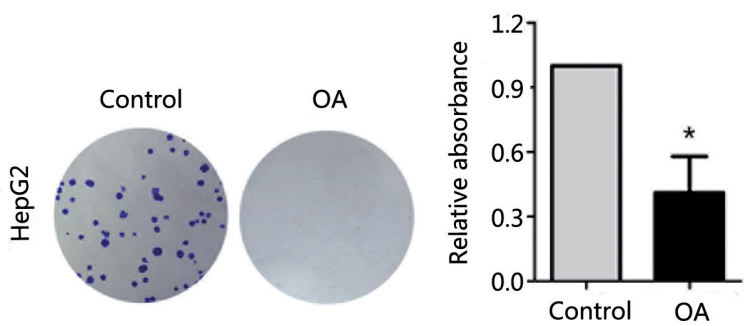

Figure 1. Effects of OA on the viability of HeLa and HepG2 cells. (A) HeLa and HepG2 cells were treated with different concentrations of OA for 24 hours. Viability of the cells was measured using an MTT assay. The experiments were repeated at least three times. The results are presented as the mean $\pm \mathrm{SD}$. ${ }^{\star}$ Stands for $\mathrm{p}<0.01$ as compared with OA-untreated group. (B) Morphology of HeLa and HepG2 cells treated with OA. HeLa and HepG 2 cells were treated with 75 mM OA for 0 and 24 hours. Morphological changes of the cells were observed under an inverted microscope. (C) Colony formation assay. HepG2 cells were seeded in a six-well plate at a density of 200 cells per well for 24 hours and then treated with 0 (cont) or $75 \mathrm{mM}$ OA for 7-10 days. Cell colonies were fixed in methanol and stained with $0.1 \%$ crystal. Dye in the colonies was extracted with $10 \%$ acetic acid, and the relative absorbance was determined at $595 \mathrm{~nm}$ by a spectrophotometer. The experiments were repeated at least three times. The results are presented as the mean \pm SD. ${ }^{\star}$ Stands for $\mathrm{p}<0.01$ as compared with OA-untreated control (cont).
OA on a normal hepatic cell line, LO-2, using MTT assays. The decrease in LO-2 cell viability was observed at 24 hours after the cells were treated with $75 \mathrm{mM} \mathrm{OA}$, and the slope change of the inhibition curve of LO-2 cells by OA was not significant compared with that of HepG2 cells by OA. The IC50 value of OA for the inhibition of the normal hepatic cell line LO-2 cell was $90.28 \pm 0.23 \mathrm{mM}$. Under an optical microscope, HepG2 cells showed significant differences in morphology and overall count after treatment with $75 \mathrm{mM}$ OA vs. the control for 24 hours. HeLa cells showed no changes under the same conditions (Figure 1B). Colony formation was also significantly reduced by treating the cells with $\mathrm{OA}$, and the absorbance of HepG2 cells treated with $75 \mathrm{mM} \mathrm{OA}$ was $44.1 \%$ of the control value (Figure 1C). There was no change in $75 \mathrm{mM} \mathrm{OA}$-treated HeLa cells vs. the control (data not shown).

Effects of $\mathrm{OA}$ on cell death, Bax/Bcl-2 mRNA expression and caspase 3 activity of HepG2 cells. After treatment with $75 \mathrm{mM}$ of OA for 24 hours, HepG2 cells became apoptotic. The distribution of apoptotic HepG2 cells was determined by flow cytometry, and the results showed that the numbers of early and late-apoptotic HepG2 cells were $21.63 \pm 2.64 \%$ of the total cells, which was significantly higher than that of non-OA treated control cells at $6.17 \pm 1.47 \%$ (Figure 2A and B). RT-PCR analysis indicated that the expression of Bax mRNA was increased and the expression of Bcl-2 mRNA was decreased in the HepG2 cells treated with $75 \mathrm{mM}$ OA in a time-dependent manner. After HepG2 cells were treated with $75 \mathrm{mM}$ OA for 1 hour or 3 hours, the ratio of $\mathrm{Bax} / \mathrm{Bcl}-2$ mRNA, a biomarker of apoptosis, was 1.3- or 2.5-fold that of the non-OA treated control cells respectively(Figure 2C and D). Caspase-3 activity, another biomarker of apoptosis, was significantly increased after HepG2 cells were treated with $75 \mathrm{mM}$ of OA for 4 hours and was 1.2-fold of non-OA-treated control HepG2 cells (Figure 2E).

Effect of OA on ROS accumulation in HepG2 cells. ROS accumulation in HepG2 cells was increased by treatment with $\mathrm{OA}$ and alleviated by the antioxidant NAC. After HepG2 cells were treated with $75 \mathrm{mM} \mathrm{OA}$ for 12 hours, cellular fluorescence intensity, a measure of ROS accumulation, was 1.9-fold that of the non-OA-treated control HepG2 cells. The increase in the fluorescence intensity treated by OA was returned to approximately $90 \%$ of the control value by simultaneous treatment with NAC (Figure $3 \mathrm{~A}$ and $\mathrm{B}$ ).

Effects of antioxidants on viability and the $\mathrm{Bax} / \mathrm{Bcl}-2$ mRNA ratio of HepG2 cells treated with $\mathrm{OA}$. The antioxidants NAC and GSH rescued the viability of HepG2 cells treated with OA. After HepG2 cells were treated with $75 \mathrm{mM}$ (or $150 \mathrm{mM}$ ) OA and 5, 10 or $20 \mathrm{mM} \mathrm{NAC}$ for 12 hours, the ratio of absorbance, an index of viability measured by MTT assays, in these treated cells to the HepG2 cells treated with $75 \mathrm{mM}$ (or $150 \mathrm{mM}$ ) OA only was $1.09 \pm 0.006(1.20 \pm 0.068)$, $1.21 \pm 0.011(1.69 \pm 0.23)$, and $1.30 \pm 0.001(2.57 \pm 0.71)$, respectively (Figure 4A and 4B). For GSH, the ratio was $1.08 \pm 0.003$ $(1.21 \pm 0.017), 1.24 \pm 0.008(1.6 \pm 0.043)$, and $1.40 \pm 0.024$ $(2.25 \pm 0.008)$, respectively (Figure $4 \mathrm{C}$ and $4 \mathrm{D})$. Based on 
A

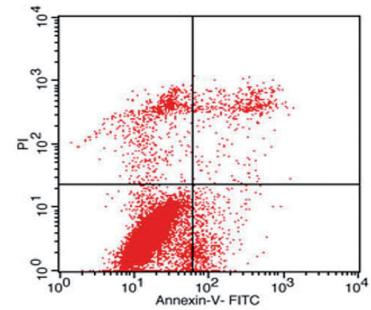

Control

B

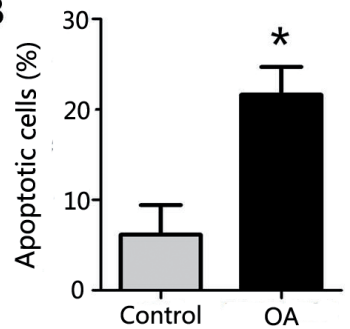

D

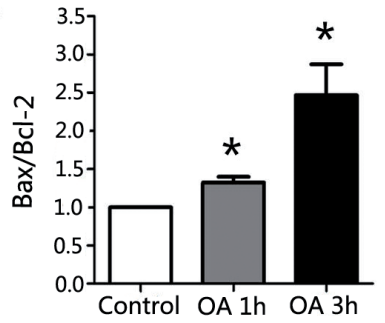

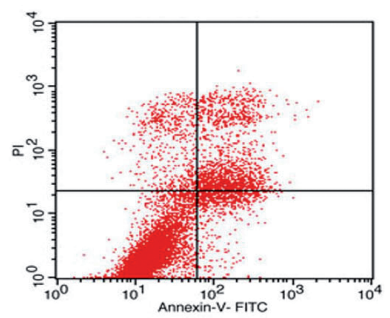

$\mathrm{OA}$

C

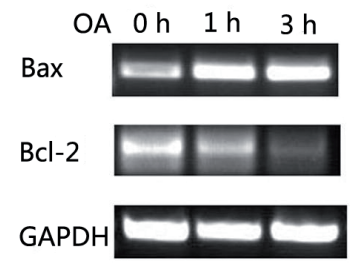

$E$

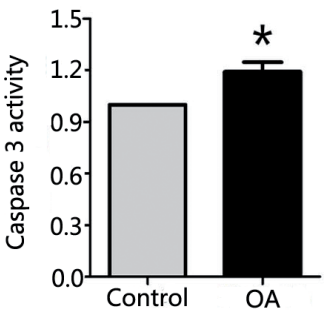

Figure 2. Flow cytometric analysis of cell death. (A) HepG2 cells were treated with 0 (control) or $75 \mathrm{mM}$ OA for 24 hours and then harvested and double stained with Annexin V-FITC and PI. The cells were sorted by a flow cytometer. (B) The apoptotic cells represent early and late apoptotic cells (bottom right and up right). Data are expressed as the mean \pm SD of three separate experiments. ${ }^{*}$ Stands for $\mathbf{p}<0.01$ as compared with OA-untreated control. (C) Apoptosis of HepG2 cells induced by OA. The mRNA levels of Bax, Bcl-2 and GAPDH in HepG2 cells were determined by RT-PCR. The mRNA levels of GAPDH were used as a loading control. (D) The levels of $\mathrm{Bcl}-2$ and $\mathrm{Bax}$ mRNA were quantitatively analyzed with an image analyzer and expressed as the ratio of Bax/Bcl-2. ${ }^{*}$ Stands for $\mathbf{p}<0.01$ as compared with OA-untreated control group. (E) Caspase- 3 activity assay. Caspase- 3 activity was assayed after HepG2 cells were treated with 0 (control) or $75 \mathrm{mM}$ OA for 4 hours. The experiment was repeated for three times. Data are presented as mean $\pm \mathrm{SD} .{ }^{\star}$ Stands for $\mathbf{p}<0.01$ as compared with $\mathrm{OA}$-untreated control group.

the results above, the restorative effects of NAC and GSH on the viability of HepG2 cells treated with OA was better for $150 \mathrm{mM}$ OA treated cells than those treated with $75 \mathrm{mM}$ OA. OA also increased the ratio of Bax/Bcl-2 mRNA, which could not be alleviated by NAC or GSH. The increase in the viability of HepG2 cells treated with OA by NAC or GSH could not be direct actions of on HepG2 cells, as NAC or GSH did not increase the viability of HepG2 cells with no OA. At concentrations of 5, 10 and $20 \mathrm{mM}$ of NAC or GSH, the viability of HepG2 cells was $86.5 \%, 88.3 \%$ and $84.0 \%$ for GSH and $94.6 \%, 100 \%$ and $84 \%$ for NAC of the control value, respectively. After HepG2 cells were treated with $75 \mathrm{mM}$ OA

A

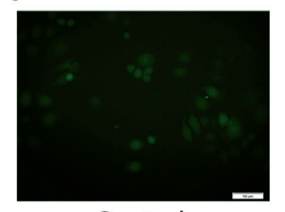

Control

B

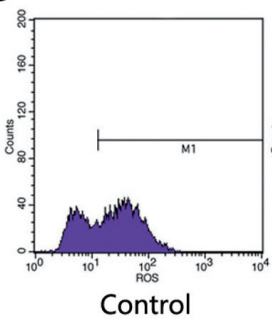

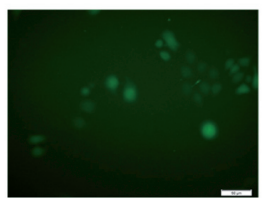

OA
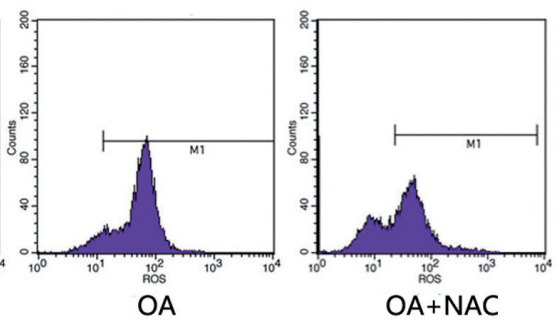

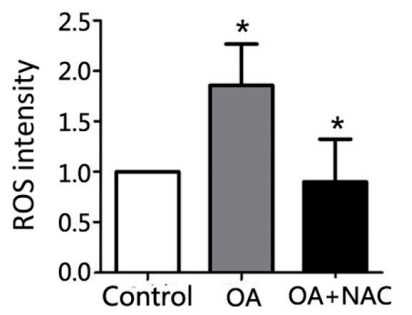

Figure 3. Accumulation of reactive oxidative species (ROS) induced by $O A$. (A) HepG2 cells were treated with HepG2 cells were treated with $0 \mathrm{mM}$, $75 \mathrm{mM} \mathrm{OA}$, or $75 \mathrm{mM}$ OA plus $20 \mathrm{mM}$ anti-oxidant NAC for 16 hours and incubated with DCFH-DA probe for 20 minutes. The intensity of green fluorescence reflecting the level of ROS was observed with a fluorescence microscope. (B) HepG2 cells were treated with $0 \mathrm{mM}, 75 \mathrm{mM}$ OA, or $75 \mathrm{mM}$ OA plus 20mM NAC for 16 hours. After incubating with DCFH-DA probe for 20 minutes, the intensity of the green fluorescence in the cells was quantitatively analyzed by flow cytometry. The experiment was repeated for at least three times. Data are presented as mean $\pm S D$, ${ }^{\star}$ Stands for $\mathbf{p}<0.01$ as compared with untreated control group.

or $75 \mathrm{mM}$ OA plus $20 \mathrm{mM}$ of the anti-oxidants NAC or GSH for 3 hours, mRNA expression of Bax or Bcl-2 in these cells was assayed by RT-PCR. The ratio of Bax/Bcl-2 mRNA was $2.49 \pm 0.082,2.44 \pm 0.054$, and $2.5 \pm 0.054$-fold that of non-OAtreated HepG2 cells in HepG2 cells treated with OA, OA plus NAC or OA plus GSH, respectively. There were no significant changes of the ratio of $\mathrm{Bax} / \mathrm{Bcl}-2$ mRNA between these treated cells (Figure 4F).

\section{Discussion}

$\mathrm{OA}$ is a well-known intermediate of the Krebs cycle. In addition to its role in cellular metabolism, OA has been reported to be able to promote cell proliferation through an obscure mechanism [3]. We hypothesized that OA may have other direct biological effects on the cells via a mechanism unrelated to its metabolic roles. Surprisingly, our study showed that OA exhibited a cytotoxic effect on HepG2 cells. There were three key findings in the present study: 1) OA decreased 
A

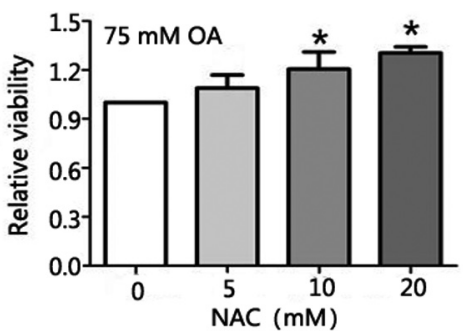

C

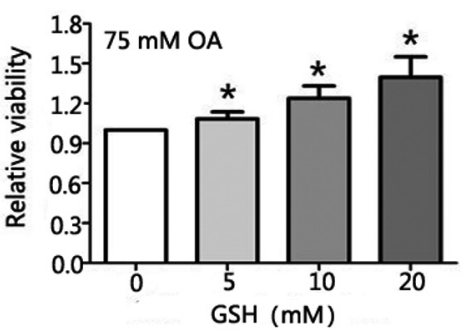

E

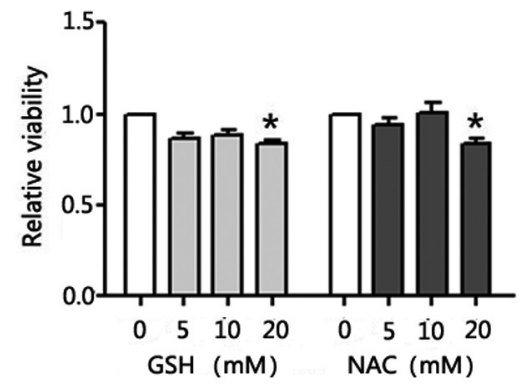

B

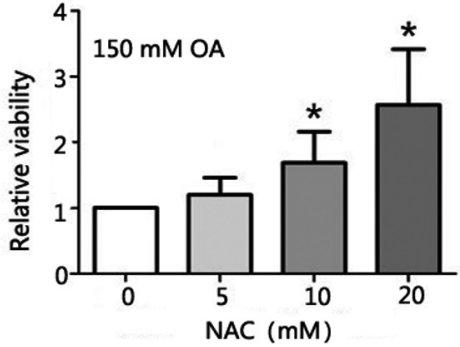

D

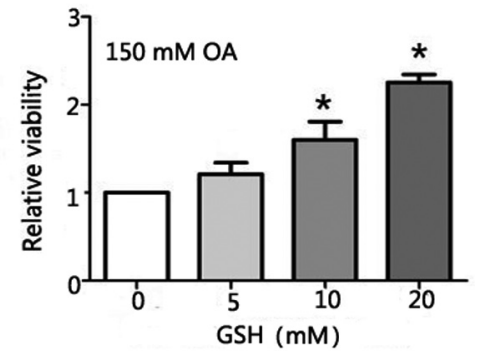

F

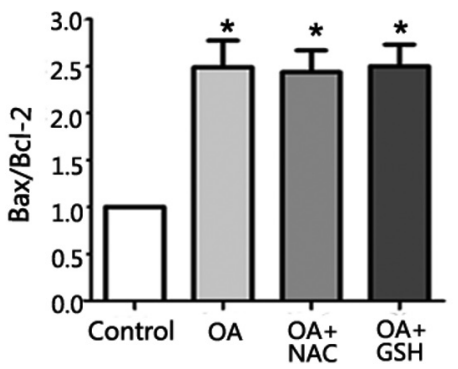

Figure 4. Effects of anti-oxidants on HepG2 cells treated with OA. HepG2 cells were treated with 75 mM OA and different concentrations of NAC (A) or GSH (C), or treated with $150 \mathrm{mM}$ OA and different concentrations of NAC (B) or GSH (D) for 12 hours. The viability of HepG2 cells was measured with a MTT assay. (E) HepG2 cells were treated with different concentrations of GSH or NAC for 12 hours. The viability of HepG2 cells was measured with MTT assays. (F) HepG2 cells were treated with $75 \mathrm{mM}$ OA or $75 \mathrm{mM}$ OA plus $20 \mathrm{mM}$ anti-oxidants NAC or GSH for 3 hours. The mRNA levels of Bax and Bcl-2 were measured using the RT-PCR assay. The experiments were repeated at least three times. The results are presented as the mean \pm SD. * Stands for $\mathrm{p}<0.01$ as compared with untreated control group.

the viability and numbers of HepG2 cells and this effect was cell type dependent as HeLa cells had no such response; 2) OA induced apoptosis of HepG2 cells through the intrinsic pathway of apoptosis; 3) the cytotoxic effect of OA on HepG2 cells was mediated not only via apoptosis, but through ROS accumulation as well.

The differential effects of OA on the viability of HepG2 and HeLa cells may reflect different cellular responses to adjacent bioactive substances as a result of varying genetic backgrounds. Cells expressing higher levels of oncogene c-Myc were shown to be highly vulnerable to apoptotic injures [17, 18]. Therefore, we examined and compared the expression of metabolism-regulating oncogenes including c-Myc, c-Jun and c-Fos and k-Ras in HepG2 and HeLa cells [19-21]. We found that expressions of these genes in both HepG2 and HeLa cell lines were decreased except for c-Myc in HepG2 cells, which was significantly elevated (data not shown). The differential expression levels of c-Myc may explain the different responses of HepG2 and HeLa cells to OA. The increase in the ratio of Bax/Bcl-2 mRNA expression and caspase 3 activities in HepG2 cells in the present study suggested that apoptotic injury may be responsible for the cytotoxic effects of OA on HepG2 cells. The increase in the ratio of $\mathrm{Bax} / \mathrm{Bcl}-2 \mathrm{mRNA}$ expression in the OA-treated HepG2 cells indicates that intrinsic apoptotic pathway may mediate the cytotoxic effects of OA on HepG2 cells [22-24].

ROS accumulation also contribute to the selective cytotoxic effect of OA on HepG2 cells. Tumor cells with high c-Myc expression have been reported to be metabolically active. These cells have a relatively high ROS content and are sensitive to apoptosis [25-27]. Apoptosis and ROS both contribute to cell death but have a contradictory relationship: ROS can either elicit cellular apoptosis through the intrinsic pathway or inhibit it [28], while our results showed that OA-induced ROS accumulation in HepG2 cells did not affect OA-induced apoptosis. Although the antioxidants NAC or GSH could prevent 
the OA-induced decrease in viability of HepG2 cells, neither NAC nor GSH could alleviate the OA-induced increase in the $\mathrm{Bax} / \mathrm{Bcl}-2$ mRNA ratio of the cell. Lower levels of ROS have been reported to induce apoptosis, while higher levels of ROS induce a necrosis $[29,30]$. The ROS levels in the OA-treated HepG2 cells in our study were relatively high, which can induce non-apoptotic cell death. Glutamate consumption may be responsible for the ROS accumulation in HepG2 cells induced by OA. OA is a catalytic substrate of aspartate-aminotransferase through which OA consumes a large amount glutamate, which reacts with alpha ketoglutaric acid to generate aspartic acid [31]. Glutamate is involved in glutathione synthesis, which can increase the intracellular antioxidant capacity[32, 33]. Glutamate consumption by OA in HepG2 cells may result in a decrease in glutathione content, which promotes accumulation of ROS inside the cell.

The cytotoxic effects of OA on HepG2 cells may be due to the amount of OA we used, which was greater than the requirement of the cells for OA. In the present study, $75 \mathrm{mM} \mathrm{OA}$ caused a cytotoxic effect on HepG2 cells, while 20-30 mM OA increased cell proliferation (data not shown). The latter finding is consistent with a published report in which $30 \mathrm{mM} \mathrm{OA}$ promoted DNA synthesis in cultured primary hepatocytes [4]. Therefore, for a given cell, OA hemostasis maintains normal function. Our study also demonstrated that NAC and GSH prevented the decrease in viability of HepG2 cells induced by OA but could not reverse the enhanced apoptotic Bax/ Bcl-2 mRNA ratio, which suggests that at least two distinct mechanisms, one mediated by ROS and one involving apoptosis, lead to the cytotoxic effect of OA on HepG2 cells. These studies expand the biological functional repertoire for $\mathrm{OA}$ and provide a mechanism by which hepatocellular carcinoma may be targeted by OA.

Acknowledgements: Support for this study was provided by the National Natural Science Foundation of China (No. 31571443 to QY), the Jilin Provincial Science and Technology Department (No. 20140414031GH and No. 20150101121JC to QY), and the Health and Family Planning Commission of Jilin Province (No. 2014 Z068 to QY).

\section{References}

[1] CAMPOS F, SOBRINO T, RAMOS-CABRER P, CASTILLO J. Oxaloacetate: A novel neuroprotective for acute ischemic stroke. Int J Biochem Cell Biol 2012; 44: 262-265. https://doi. org/10.1016/j.biocel.2011.11.003

[2] DeBERARDINIS RJ, MANCUSO A, DAIKHIN E, NISSIM I, YUDKOFF $\mathrm{M}$ et al. Beyond aerobic glycolysis: transformed cells can engage in glutamine metabolism that exceeds the requirement for protein and nucleotide synthesis. Proc Natl Acad Sci U S A 2007; 104: 19345-19350. http://dx.doi. org/10.1073/pnas.0809747104

[3] LE A, LANE AN, HAMAKER M, BOSE S, GOUW A et al. Glucose-independent glutamine metabolism via TCA cycling for proliferation and survival in B cells. Cell Metab 2012; 15: 110-121. https://doi.org/10.1016/j.cmet.2011.12.009

[4] LI Y, SATTLER GL, PITOT HC. Oxaloacetate induces DNA synthesis and mitosis in primary cultured rat hepatocytes in the absence of EGF. Biochem Biophys Res Commun 1993; 193: 1339-1346. https://doi.org/10.1006/bbrc.1993.1772

[5] YUNEVA M, ZAMBONI N, OEFNER P, SACHIDANANDAM R, LAZEBNIK Y. Deficiency in glutamine but not glucose induces MYC-dependent apoptosis in human cells. J Cell Biol 2007; 178: 93-105. https://doi.org/10.1083/ jcb.200703099

[6] QING G, LI B, VU A, SKULI N, WALTON ZE et al. ATF4 Regulates MYC-Mediated Neuroblastoma Cell Death upon Glutamine Deprivation. Cancer Cell 2012; 22: 631-644. https://doi.org/10.1016/j.ccr.2012.09.021

[7] JEONG YM, LEE JE, KIM SY, YUN HY, BAEK KJ et al. Enhanced effects of citrate on UVB-induced apoptosis of B16 melanoma cells. Pharmazie 2009; 64: 829-833.

[8] KRUSPIG B, NILCHIAN A, ORRENIUS S, ZHIVOTOVSKY B, GOGVADZE V. Citrate kills tumor cells through activation of apical caspases. Cell Mol Life Sci 2012; 69: 4229-4237. https://doi.org/10.1007/s00018-012-1166-3

[9] XU X, LI B, HUANG P, WAN X, QIN Y et al. Citrate induces apoptosis of the acute monocytic leukemia U937 cell line through regulation of HIF-1a signaling. Mol Med Rep 2013; 8: 1379-1384. https://doi.org/10.3892/mmr.2013.1702

[10] JEMAL A, BRAY F, CENTER M, FERLAY J, WARD E et al. Global cancer statistics. CA Cancer J Clin 2011; 61: 69-90. https://doi.org/10.3322/caac.20107

[11] BOSCH F, RIBES J, DIAZ M, CLERIES R. Primary liver cancer: worldwide incidence and trends. Gastroenterology 2004; 127: 5-16. https://doi.org/10.1053/j.gastro.2004.09.011

[12] HUANG Q, TAN Y, YIN P, YE G, GAO P et al. Metabolic characterization of hepatocellular carcinoma using nontargeted tissue metabolomics. Cancer Res 2013; 73: 4992-5002. http://dx.doi.org/10.1158/0008-5472

[13] JI J, SHI J, BUDHU A, YU Z, FORGUES M et al. MicroRNA expression, survival, and response to interferon in liver cancer. N Engl J Med 2009; 361: 1437-1447. https://doi.org/10.1056/ NEJMoa0901282

[14] DeBERARDINIS RJ, THOMPSON CB. Cellular metabolism and disease: what do metabolic outliers teach us? Cell 2012; 148: 1132-1144. . https://doi.org/10.1016/j.cell.2012.02.032

[15] LU Y, ZHANG X, ZHANG H, LAN J, HUANG G et al. Citrate induces apoptotic cell death: a promising way to treat gastric carcinoma? Anticancer Res 2011; 31: 797-805.

[16] YANG S, WANG X, CONTINO G, LIESA M, SAHIN E et al. Pancreatic cancers require autophagy for tumor growth. Genes Dev 2011; 25: 717-729. https://doi.org/10.1101/ $\operatorname{gad} .2016111$

[17] JUIN P, HUEBER AO, LITTLEWOOD T, EVAN G. c-Mycinduced sensitization to apoptosis is mediated through cytochrome c release. Genes Dev 1999; 13: 1367-1381. https:// doi.org/10.1101/gad.13.11.1367

[18] NIEMINEN A, ESKELINEN VM, HAIKALA HM, TERVONEN TA, YAN Y et al. Myc-induced AMPK-phospho p53 pathway activates Bak to sensitize mitochondrial apoptosis. 
Proc Natl Acad Sci U S A 2012; 110: 1839-1848. https://doi. org/10.1073/pnas.1208530110

[19] SON J, LYSSIOTIS CA, YING H, WANG X, HUA S et al. Glutamine supports pancreatic cancer growth through a KRAS-regulated metabolic pathway. Nature 2013; 496: 101-105. . https://doi.org/10.1038/nature12040

[20] GAO P, TCHERNYSHYOV I, CHANG TC, LEE YS, KITA K et al. c-Myc suppression of miR-23a/b enhances mitochondrial glutaminase expression and glutamine metabolism. Nature 2009; 458: 762-765. https://doi.org/10.1038/nature07823

[21] LI R, WEI M, SHAO J. Effects of verapamil on the immediateearly gene expression of bone marrow mesenchymal stem cells stimulated by mechanical strain in vitro. Med Sci Monit Basic Res 2013; 19: 68-75. https://doi.org/10.12659/MSMBR.883790

[22] CHEN Y, MA J, WANG F, HU J, CUI A et al. Amygdalin induces apoptosis in human cervical cancer cell line HeLa cells. Immunopharmacol Immunotoxicol 2013; 35: 43-51. https:// doi.org/10.3109/08923973.2012.738688

[23] SINGH N, SARKAR J, SASHIDHARA KV, ALI S, SINHA S. Anti-tumour activity of a novel coumarin-halcone hybrid is mediated through intrinsic apoptotic pathway by inducing PUMA and altering Bax/Bcl-2 ratio. Apoptosis 2014; 19: 1017-1028. https://doi.org/10.1007/s10495-014-0975-2

[24] GALLUZZI L, KEPP O, KROEMER G. Mitochondria: master regulators of danger signalling. Nat Rev Mol Cell Biol 2012; 13: 780-788. https://doi.org/10.1038/nrm3479

[25] TANAKA H, MATSUMURA I, EZOE S, SATOH Y, SAKAMAKI T et al. E2F1 and c-Myc potentiate apoptosis through inhibition of NF-kB activity that facilitates MnSOD-mediated ROS elimination. Mol Cell 2002; 9: 1017-1029. https://doi. org/10.1016/S1097-2765(02)00522-1
[26] VAFA O, WADE M, KERN S, BEECHE M, PANDITA TK et al. c-Myc can induce DNA damage, increase reactive oxygen species, and mitigate p53 function: a mechanism for oncogene-induced genetic instability. Mol Cell 2002; 9: 1031-1044. https://doi.org/10.1016/S1097-2765(02)00520-8

[27] PELENGARIS S, KHAN M, EVAN G. c-MYC: more than just a matter of life and death. Nat Rev Cancer 2002; 2: 764-776. https://doi.org/10.1038/nrc904

[28] SIMON H, HAJ-YEHIA A, LEVI-SCHAFFER F. Role of reactive oxygen species (ROS) in apoptosis induction. Apoptosis 2000; 5: 415-418. https://doi.org/10.1023/A:1009616228304

[29] WEDI B, STRAEDE J, WIELAND B, KAPP A. Eosinophil apoptosis is mediated by stimulators of cellular oxidative metabolisms and inhibited by antioxidants: involvement of a thiol-sensitive redox regulation in eosinophil cell death. Blood 1999; 94: 2365-2373.

[30] CAO CZ, YANG SJ, BU LS, YANG TS. Study on apoptotic and nonapoptotic injuries induced by hydrogen peroxide in cardiac myocytes. Chin J Pathophysiol 2000; 16: 457-461.

[31] DAYE D, WELLEN KE. Metabolic reprogramming in cancer: unraveling the role of glutamine in tumorigenesis. Semin Cell Dev Biol 2012; 23: 362-369. https://doi.org/10.1016/j. semcdb.2012.02.002

[32] NEWSHOLME P, PROCOPIO J, LIMA MM, PITHON-CURI TC, CURI R. Glutamine and glutamate-their central role in cell metabolism and function. Cell Biochem Funct 2003; 21: 1-9. https://doi.org/10.1002/cbf.1003

[33] SUZUKI S, TANAKA T, POYUROVSKY MV, NAGANO H, MAYAMA T et al. Phosphate-activated glutaminase (GLS2), a p53-inducible regulator of glutamine metabolism and reactive oxygen species. Proc Natl Acad Sci U S A 2010; 107: 7461-7466. https://doi.org/10.1073/pnas.1002459107 